\title{
MENYOAL PERAN DAN FUNGSI MASJID PEMERINTAH: Studi atas Masjid Agung Syuhada Polewali Mandar Makassar
}

\author{
Husnul Fahimah Ilyas \\ Balai Penelitian dan Pengembangan Agama Makassar \\ E-mail:husnul_natalia@yahoo.com
}

\begin{abstract}
This policy genre study aims to identify the management, the function and the role of Great Mosque Syuhada in Polewali Mandar. It will also describe the physical condition and historical building of the mosque. The conducted qualitative research was based on interview, observation, document, and literature. The findings of the research show that the position of the grand mosque is assumed to be a representative mosque at the district level, and the provincial-level mosque that serves as a model of service and management that meets the standards, but the facts on the ground show that the management system and its management are still below the standard, which does not meet the standards imposed by the directorate of religious affairs of Islam and syariah. The roles and functions played by the Great Mosque or Masjid Agung Syuhada was limited to regular worship services, recitation, and implementation of great days of Islam.
\end{abstract}

Keywords: Activities; Mosque; Management; Polewali Mandar; Service

\begin{abstract}
ABSTRAK
Penelitian ini bertujuan untuk mengetahui pengeloaan, fungsi, dan peran masjid Agung Syuhada sebagai masjid kabupaten Polewali Mandar, serta mendeskripsikan kondisi fisik dan sejarah pembangunan masjid tersebut. Penelitian kualitatif yang dilakukan berdasarkan pada wawancara, observasi, dokumen, dan pustaka. Temuan penelitian ini menunjukkan sistem pengelolaan masjid Agung Syuhada Polewali Mandar masih di bawah standar, belum sesuai dengan standar yang diberlakukan oleh Direktorat Urusan Agama Islam dan Syariah.
\end{abstract}


Sedangkan peran dan fungsi yang dimainkan oleh Masjid Agung Syuhada Polewali Mandar hanya sebatas pada pelayanan ibadah rutin, pengajian dasar secara tradisional, dan pelaksanaan HBI (Hari Besar Islam).

Kata kunci: Fungsi; Masjid; Pengelolaan; Peran; Polewali Mandar

\section{A. Pendahuluan}

Keberadaan masjid disuatu daerah pertanda terdapat kaum muslim yang berdomisili, atau tempat tersebut pernah hidup atau dikuasai oleh kaum muslimin.

Masjid dalam dinamika perkembangan Islam, baik di zaman Rasulullah saw maupun dewasa ini sangat berperan dalam kehidupan masyarakat Islam. Salah satunya berperan sebagai benteng aqidah dalam kehidupan kaum muslimin, itulah sebabnya Allah swt dan Rasul-Nya mewajibkan kaum muslimin membangun mesjid atas dasar taqwa.

Secara tekstual masjid berarti bersujud, sedangkan secara konsektual masjid berfungsi sebagai tempat penyelesaian berbagai masalah umat, jadi sejak awal masjid memilikimulti fungsi(Amidan1980,13) dan sebagai pusat aktivitas kegiatan pembinaan umat yang memiliki dimensi luas. Oleh sebab itu diperlukan suatu pengelolaan manajerial secara profesional sesuai dengan perkembangan masyarakat yang dilayanisebagai pusat kegiatan ibadah dan kebudayaan Islam.(Gazalba 1975, 7). Karena di dalam masjid semua masyarakat mempunyai hak dan kewajiban yang samadalam pelayanan (Syahidin2004, 39).

Jadi masjid bukan sekedar tempat peribadatan ritusyang terbatas sebagai perwujudan pendekatan diri (ubudiyah) seorang hamba dalam ibadah mahdah, tetapi disisi muamalat, masjid juga sebagai pusat terbentuk dan terciptanya peradaban Islam dan merupakan sentral pengembangan sebagai aktivitas dalam hidup serta kehidupan kaum muslimin.

Sepanjang rentang sejarah Islam, masjid memang telah menjadi ikon syiar Islam yang terbesar. Ketika Nabi Muhammad hijrah ke Yasrib (Madinatun Nabi atau Madinatul Munawwarah) lembaga yang pertama didirikan adalah masjid (Yatim2006, 25).Dimasjid disemaikan segala sesuatu yang bernilai amal kebijakan, baik yang berdimensi dan bernuansa ukhrawiyah yang transenden maupun yang bernuansa duniawiyah 
dalam sebuah garis kebajikan dan kemaslahatan umat.Rasulullah sendiri memposisikan masjid sebagai basis transformasi wahyu dan menyusun agenda-agenda politik. Masjid dijadikan sebagai arena dialektika pengetahuan antara nabi Muhammad dan para sahabatnya. Para tabi-tabiin seperti Imam Hanifah di Kufah, Imam Malik di Madina, Imam Syaf'i di Bagdad, Imam Hasan Basri di Basrah, semuanya menjadikan masjid sebagai pusat transmisi pengetahuan. Sederat ulama yang ternama dalam sejarah, lahir karena mereka memfungsikan masjid sebagai pusat kegiatan. Dengan begitu masjid memiliki posisi yang sangat penting dalam kehidupan sosial umat Islam.

Perhatian pemerintah terhadap kemasjidan cukup tinggi.Hal ini ditandai dengan didirikannya atau ditetapkannya sebuah masjid berkaitan dengan struktur pemerintahan, mulai dari pusat sampai ditingat kelurahan. Pembangunan dan pembinaan masjid ditopang oleh anggaran pemerintah setempat dan dana masjid. Perbedaan penamaan masjid tergantung pada letak wilayah masjid seperti masjid negara di tingkat pemerintahan pusat, masjid raya ditingkat provinsi, masjid agung ditingkat kabupaten/ kota, masjid besar ditingkat kecamatan, dan masjid jami ditingkat desa atau kelurahan.

Fungsi masjid berdasarkan hasil seminar Badan Kesejahteraan Masjid (BKM) tahun 1975 mengidentifikasi fungsi masjid sebagai pusat ibadah dan pusat kegiatan masyarakat.Keputusan seminar tersebut menyatakan rincian fungsi masjid sebagai pusat peribadatan, yaitu tempat shalat dan i'tiqaf; serta sebagai pusat kegiatan kemasyarakantan yang meliputi pendidikan formal dan non-formal,ibadah sosial,usaha di bidang kesehatan, pembainaan remaja, peringatan hari-hari besar Islam, serta sebagai sarana komunikasi.

Selanjutnya tipologi masjid berdasarkan Direktorat Urusan Agama Islam dan Pembinaan Syariah, dikemukakan peningkatan pemanfaatan masjid sebagai tempat ibadah, tempat musyawarah, tempat perlindungan, tempat kegiatan sosial, tempat latihan dan siasat perang, tampat pengobatan, dan tempat pendidikan(Direktorat Urusan Agama Islam2007, 68), yangdikategorikan dalam pembinaan idarah, ri'ayah, imarah, dan ri’ayah (Direktorarat Jenderal Bimbingan Masyarakat Islam2000). 
Pembinaan idarah adalah pembinaan kegiatan yang menyangkut administrasi, manajemen dan organusasi masjid. Pembinaan imarah adalah suatu usaha untuk memakmurkan masjid sebagai tempat ibadah, pembinaan umat, dan peningkatan kesejahteraan jemaah. Pembinaan riayah adalah memelihara masjid dari segi bangunan, keindahan, dan kebersihan.

Luasnya cakupan, peran, dan fungsi yang diemban oleh masjid, maka agar pengelolaannya (pembinaannya) dapat berjalan baik dan efektif diperlukan manajemen yang baik. Manajemen atau pengelolaan adalah sebuah proses yang dilakukan untuk mewujudkan tujuan organisasi melalui rangkaian kegiatan berupa perencanaan, pengorganisasian, pengerahan, dan pengendalian orang-orang serta sumber daya organisasi lainnya atau sering disebut PAOC-planning, organizing, actuating, dan controlling (Sule dan Kurniawan Saefullah2008, 6). Unsur manajemen meliputi: man, money, material, dan metode. Teknik-teknik manajemen mencakup: kepemimpinan koordinasi, komunikasi dan lain-lain (Muslim2004,106-107).

Manajemen masjid dapat dibagi berdasarkan pertama manajemen bidang idarah yang meliputi perencanaan, pengorganisasian, pengadministrasian, keuangan, dan pengawasan. Kedua manajemen bidang imaroh yang diarahkan pada usaha untuk memakmurkan masjid sebagai tempat ibadah, pembinaan umat, dan meningkatkan kesejahteraan jemaah. Ketiga manajemen bidang riayah lebih memfokuskan pada pengembangan sarana dan prasarana masjid(Direktorat Urusan Agama Islam2008).

Berdasarkan pemaparan tersebut diatas maka persoalan yang diangkat dalam tulisan ini adalah bagaimana pengelolaan masjid Agung Syuhada Polewali Mandar dan bagaimana peran dan fungsinya di tengahtengah masyarakat dalam pembangunan umat. Dalam mengkaji persoalan tersebut penelitian ini menggunakan metode kualitatif deskriptif yakni berusaha menghasilkan data deskriptif, gambaran yang sistematis, sifat-sifat serta hubungan-hubungan antara fenomena yang diamati. Fokus penelitian membahas mengenai model manajemen pengelolaan mesjid Syuhada Polewali Mandar termasuk sistem pelayanannya dalam meningkatkan kegiatan keagamaan dan sosial. Data yang dikumpulkan dijelaskan secara deskriptif, dan memberikan kejelasan objek dan subjek penelitian terutama menggambarkan serta peran-peran yang telah dimainkan oleh 
Masjid Syuhada Polewali Mandar. Teknik dalam menetapkan informan menggunakan purposive sampling, kriteria informan adalah mereka yang memahami situasi sosial masjid. Para informan terdiri atas pengurus masjid, imam masjid, jamaah masjid, dan masyarakat yang berdomisili sekitar masjid. Data yang terkumpul dianalisis berdasarkan ketentuan Bimas Islam dalam Pedoman Pemberdayaan Masjid (2007).

\section{B. Pembahasan}

\section{Sejarah Pendirian Masjid Agung Syuhada Polman}

Masjid Syuhada secara resmi didirikan pada tahun 1984. Berlokasi di Jl. Mr. Muh. Yamin Pekkabata, Kecamatan Polewali Kabupaten Polewali Mandar atau berada di jalan Andi Depu trans-Sulawesi. Kabupaten Polewali Mandar (Polman) sendiri, sebelumnya bernama Polewali Mamasa (Polmas), pada tahun 2002 berubah nama menjadi Kabupaten Polewali Mandar, setelah Mamasa berotonomi menjadi kabupaten tersendiri.

Masjid Syuhada yang berstatus sebagai Masjid Agung Kabupaten Polewali Mandar berdasarkan keputusan pemerintah daerah Polmas pada masa kepemerintahan S.Mengga yang memimpin Polewali Mamasa (Polmas) pada tahun 1980-1990. Sebelum Masjid Syuhada ditetapkan sebagai Masjid Agung, sebenarnya di Kabupaten Polmas (kala itu sudah terdapat masjid yang diperuntukkan sebagai masjid kabupaten, yakni Masjid Al-Abrar. Masjid Al-Abrar sendiri dibangun pada masa kepemerintahan Bupati Polmas yang pertama Andi Hasan Mangga yang memimpin Kabupaten Polmas pada tahun1960-1966.

Kondisi Masjid Al-Abrar kala itu dari segi bangunan sangat kecil dan tidak luas. Letaknya pun berada di tengah pemukiman atau perumahan warga di Pekkabata Kecamatan Polewali. Dari segi posisi, Masjid AlAbrar kurang strategis karena lokasinya yang jauh dari akses jalan raya. Berdasarkan kondisi dan letak Masjid Al-Abrar tersebut, maka masyarakat Polmas menganggap perlu adanya masjid baru yang representatif sebagai masjid kabupaten yang akan menjadi kebanggaan tersendiri bagi masyarakat Polmas.

Masjid kabupaten juga merupakan simbol dan ikon sebuah daerah yang memiliki makna tersendiri, terutama dalam relasi sosial-keagamaan 
masyarakatnya. Maka, seiring dengan tuntutan masyarakat akan kebutuhan sebuah masjid yang bisa menampung jumlah jamaah yang besar, maka diadakanlah beberapa kali pertemuan antara tokoh-tokoh masyarakat dengan dengan pihak Pemda Polmas. Dari hasil pertemuan tersebut, maka disepakati bahwa akan diadakan pembangunan sebuah masjid kabupaten, yang kelak dinamakan Masjid Syuhada. Pihak Pemda Polmas menyambut inisiasi pendirian masjid yang dipimpin oleh Bupati ketiga, Abdullah Madjid (1966-1979) dengan mempersiapkan sebuah fondasi bangunan masjid, dan mulailah di bangun Masjid Syuhada. Jadi prosesi pembangunan Masjid Syuhada melibatkan 3 (tiga) pemimpin Kabupaten Polmas, yakni Bupati Hasan Mangga dengan Masjid Al-Abrar yang diresmikan pada masa kepemimpinannya, Bupati Abdullah Madjid yang punya andil membangun fondasi sebagai calon lokasi bangunan Masjid Syuhada, dan Bupati S. Mengga yang meresmikan tersebut.

Selain dari pihak pemerintah Kabupaten Polmas kala itu, ada beberapa tokoh masyarakat dan ulama Polmas yang berandil besar dalam pembangunan Masjid Syuhada. Diantaranya adalah Alm. Annangguru Saleh, Muhsin Tahir, dan Syuaib Abdullah (yang sampai sekarang ini menjadi Imam tetap Masjid Syuhada).

Merupakan sebuah kebanggaan tersendiri pada masyarakat Polmas, karena peletakan batu pertama pada mihrab, dan untuk penentuan arah kiblat Masjid Syuhada dilakukan oleh ulama besar Sulawesi Barat bahkan termasuk Ulama besar di Sulawesi Selatan, yakni Annangguru Saleh,seorang ulama dan juga Mursyid yang sampai sekarang masih dimuliakan oleh masyarakat Sulawesi Barat.

Sedangkan peristiwa bersejarah yang lain ketika pada mula difungsikannya Masjid Syuhada yang menjadi Imam pertama K.H. Muhsin Tahir, kemudian yang membaca khutbah K.H. Umar Syihab, Muazzin H. Muhammad Ihsan, dan Syuaib Abdullah waktu itu membaca doa, yang kemudian K.H, Syuaib Abdullah inilah yang menjadi Imam masjid Syuhada sampai sekarang ini.

Peran besar lain dari para ulama dan tokoh masyarakat di atas adalah bagaimana mereka menjadi simpul, menggerakkan seluruh elemen masyarakat untuk membantu pembangunan masjid Syuhada tersebut. 
Karena sebagian besar biaya pembangunan Masjid Syuhada adalah hasil sembangsih, swadaya dan kerja keras masyarakat Polmas kala itu.

Selain itu dilibatkan juga pemuda Polmas kala itu untuk ikut dalam proses pembangunan masjid Syuhada berpatisipasi aktif dalam rapatrapat perencanaan pembangunan, terutama dalam membina generasi muda dengan nilai-nilai keagamaan melalui sarana peribadatan. Kala itu, perencanaan penganggaran untuk pembangunan Masjid Syuhada sekitar 80 juta. Ketika pembangunan Masjid Syuhada pada tahun 1984, maka angka tersebut bukanlah angka yang sedikit. Dengan jumlah anggaran tersebut, maka mesti disokong oleh semua pihak, terutama kerjasama yang harmonis antara pihak Pemda Polmas dengan masyarakat.

Untuk itulah, pada waktu awal pembangunan Masjid Syuhada, diberlakukan sumbangan dari seluruh pegawai di Polmas untuk mengikhlaskan sebagian gajinya guna pembangunannya, di samping bantuan dari masyarakat umum dan juga kerja keras dari pihak Pemda Polmas kala itu. Setelah ada kesepakatan, maka didatangkanlah seorang arsitektur dari Universitas Hasanuddin (Unhas) untuk merancang, menggambar masjid permanen kabupaten yang bisa membanggakan.

Setelah memakan waktu selama 3 (tiga) tahun, maka akhirnya pembangunan Masjid Syuhada pun selesai. Dengan wujud sebuah masjid yang cukup unik, berukuran besar berukuran 32 meter jika ditarik dari pinggir hingga ke sisi puncak kubah. Kubah masjid Syuhada tidak disangga langsung oleh tiang ditengahnya. Bentuk masjid tersebut juga untuk memenuhi harapan mayarakat akan prasarana ibadah yang representatif dan membanggakan, atau sesuai juga dengan misi awal pembangunannya, bahwa masyarakat Polmas ingin memiliki sebuah ikon daerah yang khas dan membanggakan.

Pemberian nama untuk Masjid Syuhada memiliki sejarah yang sangat demokratis, karena nama tersebut adalah hasil penyebutan yang berulang-ulang di tingkat masyarakat. Mendengar hal tersebut, maka pihak panitia pembangunan dan pengurus masjid mengahadap kepada Bupati Polmas, S. Mengga untuk meresmikan nama tersebut. Di samping terdapat unsur kesejarahan, nilai-nilai kejuangan ditingkat masyarakat yang ingin disimbolkan melalui nama masjid tersebut. Maka pada tahun 1984, Bupati S. Mengnga meresmikan masjid baru tersebut dengan nama Masjid 
Syuhada. Dijadikannya Masjid Syuhada sebagai Masjid Agung didasarkan pada beberapa alasan, diantaranya letak posisi yang sangat strategis karena berada di jantung Kabupaten Polmas kala itu. Berada di sudut perempatan jalan yang menghubungkan jalan ke Kabupaten Mamasa dan Kabupaten Mamuju-Majene-Makassar, dan beberapa alasan sederhana, karena dulu hanya berjarak beberapa puluh meter saja dengan Kantor Daerah Kabupaten Polmas (lama).

Dalam sejarah perjalanannya sudah ada beberapa tokoh yang pernah mengunjungi Masjid Syuhada, namun seiring dengan berjalannya waktu, pada tahun 2004 mulailah didakan renovasi. Meskipun sebelum itu sudah beberapa kali diadakan renovasi, perbaikan, perlengakapan sarana, dan prasarana. Namun tahun 2004 inilah cikal bakal renovasi besar-besaran yang dilakukan terhadap Masjid Syuhada. Pembicaraan awal renovasi untuk Masjid Syuhada diawali pada tahun 2004. Namun, implementasi nyata dilakukan pada tahun 2006, dengan dibangunnya beberapa pancang beton di luar masjid tersebut.

Setelah akhir tahun 2011 baru diadakan perombakan besar-besaran, termasuk merobohkan bangunan lama, yakni kubah masjid yang besar dan unik tersebut. Beberapa alasan yang terkuak diadakannya renovasi besarbesaran tersebut adalah karena masjid bangunan lama sudah tidak bisa lagi menampung jamaah yang membludak setiap diadakan shalatjumat. Alasan lain bahwa konstruksi bangunan lama yang sudah rapuh. Namun terdapat hal lain yang luar biasa dari arsitektur Masjid Syuhada (lama) yang akan diskripsikan lebih lanjut.

Penentuan arah kiblat Masjid Syuhada Polman pertamakali ditentukan oleh Annangguru Saleh pendiri tarekat Qadiriyah di Mandar (Idham2011, 92-100). Pada saat peletakan batu pertama masjid tersebut. Namun setelah Pengadilan Agama Polman melakukan pengukuran dengan menggunakan kompas dan bandul terjadi pergeseran arah kiblat. Tepatnya pada tanggal 5 November 2007 perubahan kiblat Masjid Syuhada berubah setelah Tim Pengukuran Kiblat Pengadilan Agama Polewali melakukan verifikasi yang di SK-kan pada tanggal 1 Maret 2006, Nomor: PA.t/21/K/ HK.03.2/SK.05/2006.

Setelah menerima berita acara dari PA Polman atas nama Tim Panitia Pengukuran Arah Kiblat Kabupaten Polman diadakanlah 
rapat pertemuan pada tanggal 1 Nopember 2007 yang dihadiri oleh Majelis Ulama Indonesia cabang Polewali Mandar, Departemen Agama Kabupaten Polewali Mandar, Pengadilan Agama Polewali Mandar, Panitia pemeliharaan masjid Syuhada, tokoh-tokoh agama Islam, anggota jemaah masjid Syuhada, dan pemerintah kabupaten Polewali Mandar. Dalam keputusan rapat tersebut dibahas pada poin ketiga bahwa berdasarkan penetapan Ketua Pengadilan Agama Polewali, setelah melakukan pengukuran kembali arah kiblat di Masjid Syuhada oleh ketua bersama tim PA Polewali ternyata bahwa arah kiblat Masjid Syuhada condong ke Utara dari yang sebenarnya, sehingga terjadi selisih $18^{\circ}$. Untuk itu perlu dilakukan perubahan arah kiblat dari yang sebelumnya, disesuaikan dengan penetapan Ketua PA Polewali sebagai instansi yang berkompeten dalam hal penentuan arah kiblat. Berdasarkan hal tersebut Bupati Polman mengintrusikan kepada pengelolah/panitia pemeliharaan dan Imam Masjid Syuhada Polewali pada tanggal 5 Nopember 2007 (Nomor: 450/84/Binsos) agar mengikuti arah kiblat yang ditentukan termasuk mengubah garis sahaf yang ada.

Kesepakatan yang lain dalam rapat tersebut mengukuhkan kembali masjid Syuhada Pekkataba Polewali sebagai Masjid Agung (masjid agung kabupaten) Polewali Mandar berdasarkan SK Bupati Polewali Mandar Nomor 308 tahun 2007 tanggal 23 Oktober 2007 (Dokumen Pemkab Polman). Renovasi masjid Syuhada Polewali akan dilaksanakan dengan perbaikan fisik dan perubahan arah kiblat yang lebih baik. Karena fisik bangunan lama sudah tidak dapat dipertanggungjawabkan kekuatan/ ketahanannya (kubahnya sudah banyak yang melapuh) serta suara di dalam masjid menggema.

Urutan shaf yang di Masjid Syuhada berdasarkan pada garis yang ditentukan ditegel lantai masjid setelah menerima instruksi perubahan shafnya memakai lakban hitam sebagai penanda mengatur shaf.

Sedangkan dalam aturan kewenangan pengukuran arah kiblat PA telah melimpahkan kepada Kemenag. Hal terbut bermula pada awal reformasi tahun 1999 dengan keluarnya UU No.35 tahun 1999 tentang perubahan atas UU No.14 Tahun 1970 mengenai kekuasaan kehakiman. UU No.35 tahun 1999 kemudian berubah menjadi UU No.4 Tahun 2004 mengenai kekuasaan kehakiman, proses peralihan atau biasa disebut 
kebijakn one roof system dipertegas dalam ketentuan peralhan pasal 42 dalam UU tersebut, bahwa pengalihan organisasi, administrasi, financial dalam Pengadilan Agama dan militer dilaksanakan paling lambat tanggal 30 Juni 2004, lalu berubah lagi menjadi UU No.48 Tahun 2009.

\section{Kondisi Fisik dan Arsitektur Bangunan}

Secara arsitektur, Masjid Syuhada lama sangat unik. Keunikannya terletak pada ukuran kubahnya yang sangat besar, 36 meter seluruh luas bangunan masjid ditutup dengan hanya satu kubah saja, jadi kubah tersebut sekaligus merangkap sebagai atap masjid. Saking besarnya, konon kubah Masjid Syuhada merupakan kubah terbesar di antara masjid-masjid di Sulawesi.

Keunikan arsitektur (lama)dari Masjid Syuhada adalah kubah yang sangat besar tersebut tidak ditopang oleh tiang penyangga ditengahnya. Yang menyangga kubah berdiameter 36 meter hanya 6 (enam) beton pancang pendek yang bertumpu pada cor balok blandar dibawahnya yang mengelilingi kubah tersebut. Dari blandar balok tersebut, baru ada beberapa tiang ke bawah yang mengelilingi luasan masjid sebagai penyangganya. Jadi, kubah besar tersebut hanya disangga oleh tiang yang berada di pinggir diameter kubah. Jadi sekali lagi, tidak ada tiang yang menyangga ditengah kubah besar Masjid Syuhada tersebut.

Arsitektur menara masjid Syuhada mengadobsi arsitektur menara masjid Haram Mekah. Bangunan menara tingginya sekitar 30 meter, pada awalnya bangunan menara hanya satu pada sisi sebelah selatan masjid. Pada tahun 2006 ketika Ali Baal menjadi bupati Polman menambah menera masjid menjadi dua dengan arsitektur yang sama dan menempatknnya pada sebelah utara masjid. Kedua menara tersebut masih dipertahankan sampai sekarang, sedangkan untuk bangunan lama masjid ditelah dirombak dan dirubah total dari arsitektur sebelumnya, dan kondisi masjid Syuhada untuk sekarang ini masih dalam tahap pembangunan.

Penentuan arah kiblat Masjid Syuhada Polman permakali ditentukan oleh Annangguru Shaleh pendiri pendidiri karekat qadiriyah di Mandar (selengkapnya lihat Idham. 2011) pada saat peletakan batu pertama masjid tersebut. Namun setelah Pengadilan Agama Polman melakukan pengukuran dengan menggunakan kompas dan bandul terjadi 
pergeseran arah kiblat. Tepatnya pada tanggal 5 Nopember 2007 perubahan kiblat masjid syuhada berubah setelah Tim Pengukuran Kiblat Pengadilan Agama Polewali melakukan verivikasi yang di SK-kan pada tanggal 1 Maret 2006, Nomor: PA.t/21/K/HK.03.2/SK.05/2006.

Setelah menerima berita acara dari PA Polman atas nama Tim Panitia Pngukuran Arah Kibalat Kabupaten Polman diadakanlah rapat pertemuan pada tanggal 1 Nopember 2007 yang dihadiri oleh Majelis ulama Indonesia cabang Polewali Mandar, Departemen Agama Kabupaten Polewali Mandar, Pengadilan Agama Polewali Mandar, Panitia pemeliharaan masjid Syuhada, tokoh-tokoh agama Islam, anggota jamaah masjid Syuhada, dan pemerintah kabupaten Polewali Mandar. Dalam keputusan rapat tersebut dibahas pada poin ketiga bahwa berdasarkan penetapan Ketua Pengadilan Agama Polewali, setelah melakukan pengukuran kembali arah kiblat di Masjid Syuhada oleh ketua bersama tim PA Polewali ternyata bahwa arah kiblat Masjid Syuhada condong ke Utara dari yang sebenarnya, sehingga terjadi selisih $18^{\circ}$. Untuk itu perlu dilakukan perubahan arah kiblat dari yang sebelumnya, disesuaikan dengan penetapan Ketua PA Polewali sebagai instansi yang berkompeten dalam hal penentuan arah kiblat. Berdasarkan hal tersebut Bupati Polman mengintrusikan kepada pengelolah/panitia pemeliharaan dan Imam Masjid Syuhada Polewali pada tanggal 5 Nopember 2007 (Nomor: 450/84/Binsos) agar mengikuti arah kiblat yang ditentukan termasuk mengubah garis sahaf yang ada.

Kesepakatan yang lain dalam rapat tersebut mengukuhkan kembali masjid Syuhada Pekkataba Polewali sebagai Masjid Agung (masjid agung kabupaten) Polewali Mandar berdasarkan SK Bupati Polewali Mandar Nomor 308 tahun 2007 tanggal 23 oktober 2007. Renovasi masjid Syuhada Polewali akan dilaksanakan dengan perbaikan fisik dan perubahan arah kiblat yang lebih baik. Karena fisik bangunan lama sudah tidak dapat dipertanggungjawabkan kekuatan/ketahanannya (kubahnya sudah banyak yang melapuh).

Urutan shaf yang di masjid syuhada berdasarkan pada garis yang ditentukan ditegel lantai masjid setelah menerima instruksi perubahan shafnya memakai lakban hitam sebagai penanda mengatur shaf. 


\section{Sistem Administrasi dan Kepengurusan}

Manajemen atau pengelolaan pada dasarnya merupakan seni atau proses dalam menyelesaikan sesuatu yang terkait dengan pencapaian tujuan. Dalam menyelesaikan sesuatu tersebut, terdapat tiga faktor yang terlibat pertama adanya penggunaan sumber daya organisasi, baik sumber daya manusia, maupun faktor-faktor produksi lainnya;kedua adanya proses yang bertahap dari mulai perencanaan, pengorganisasian, pengarahan, dan pengimplementasian, hingga pengendalian dan pengawasan; ketiga adanya seni dalam menyelesaikan pekerjaan (Sule dan Kurniawan Saefullah 2008, 6).

Adapun fungsi manajemen menurut Nickels dan McHugh terdiri empat fungsi pertama perencanaan atau planning yaitu proses yang menyangkut upaya yang dilakukan untuk mengantisipasi kecenderungan di masa yang akan datang dan penentuan strategi dan taktik yang tepat untuk mewujudkan target dan tujuan organisasi. Kedua pengorganisasian atau organizing merupakan proses yang menyangkut bagaimana strategi dan taktik yang telah dirumuskan dalam perencanaan didesain dalam sebuah struktur organisasi yang tepat dan tangguh, sistem dan lingkungan organisasi yang kondusif, dan bisa memastikan bahwa semua pihak dalam organisasi bisa bekerja secara efektif dan efesien guna mencapai tujuan organisasi. Ketiga pengimplementasian atau directing merupakan proses implementasi program agar bisa dijalankan oleh seluruh pihak dalam organisasi serta proses motivasi penuh kesadaran dan produktivitas yang tinggi. Keempat pengendalian atau pengawasan atau controlling merupakan proses yang dilakukan untuk memastikan seluruh rangkaian kegiatan yang telah direncanakan, diorganisasikan, dan diimplementasikan bisa berjalan sesuai dengan target yang diharapkan sekalipun berbagai perubahan terjadi dalam lingkungan yang dihadapi (Sule dan Kurniawan Saefullah2008, 8).

Sistem kepengurusan masjid syuhada terjadi perubahanperubahan. Batas kepengurusan Masjid Syuhada antara 4-5 tahun, dan pada priode kepengurusan sekarang batas waktunya selama empat tahun mulai tahun 2009-2013. Kepengurusan diSK-kan oleh Bupati Polman selaku pemerintah kabupaten.Sedangkan program yang bersifat bangunan fisik ditangani oleh panitia khusus.Pemilihan pengurus masjid tidak melalui rapat ataupun pemilihan secara langsung tetapi merupakan hak 
otoritas pemerintah daerah yang berdampak pada beberapa orang tidak mengetahui keterlibatlibatannya dalam kepengurusan masjid tersebut.

Meskipun pengurusnya telah terbentuk secara apik namun belum terdapat program kerja yang disusun berdasarkan pembagian struktur untuk pengembangan lembaga dan pelayanan. Untuk proses agenda rapat misalnya, tidak terjadwal, bahkan untuk rapat internal pengurus juga tidak teragendakan dengan jadwal. Kalaupun ada rapat pengurus di masjid Syuhada itu lebih pada situasi dan kondisi yang mengharuskan untuk itu. Jadi kegiatan rapatnya disesuaikan dengan kebutuhan atau pada waktu akan mengadakan kegiatan perayaan hari besar Islam.

Kepengurusan yang menangani masalah keuangan yang dikelola oleh bendahara masjid berdasarkan pemasukan dan pengeluaran yang bersumber dari sumbangan pemerintah, instansi, penyumbang tetap, masyarakat, jemaah masjid dipajang pada papan informasi masjid. Sedangkan dana untuk pembangunan masjid dikelola langsung oleh Pemda dan panitia renovasi masjid tanpa campur tangan dari pihak pengurus masjid.

\section{Aktivitas Pelayanan Masjid}

Selain bangunan fisik masjid yang harus menjadi pertimbangan utama, tetapi harus agar mampu mempertimbangkan segala perkembangan yang ada di masyarakat (Jasmadi 2008,86). Selajan dengan pendapat tersebut dalam Keputusan Muktamar IV Dewan Masjid Indonesia mengamanatkan tiga misi.

Pertama masjid berfungsi sebagai pusat ibadah, meliputi ibadah mahdah seperti shalat, mengaji, tahlil, tadarrus, dan lain-lain, juga ibadah gairu mahdah seperti pengelolaan zakat, wakaf, membangun ukhuwah islamiyah, menjaga keberhasilan dan kesehatan bersama, qurban, peningkatan ekonomi umat dan lain-lain.

Kedua menjadikan masjid sebagai tempat pengembangan masyarakat, melalui berbagai sarana dan prasarana di masjid, seperti melalui khutbah, kursus keterampilan, pendidikan formal, ataupun pendidikan lainnya.Ketiga menjadikan masjid sebagai tempat pembinaan persatuan umat. 
Selayaknya setiap masjid mempunyai visi dan misi khusus yang dijabarkan dari tiga visi dan misi yang dirumuskan pada muktamar tersebut. Mencermati visi dan misi di atas, terdapat relevansi sejumlah aktivitas yang dilakukan di masjid Syuhada Polman:

\section{a. Shalat Lima Waktu}

Keberadaan suatu masjid dalam suatu komunitas sosial, mengandung harapan dan tantangan yakni tugas imaratul masajid, antara lain menghidupkan shalat jamaah. Kegiatan shalatjamaah lima waktu yang dilaksanakan secara rutin yang dihadiri sejumlah jamaah yang bervariasi pada lima waktu shalat. Magrib dan Isya jamaah yang hadir hampir sama sekitar 30 orang (pria dan wanita). Shalat jemaah subuh sekitar 20 orang, sedangkan shalat Dhuhur dan Ashar bisa di atas 30 orang dan bisa juga di bawah dari jumlah tersebut. Jumlah jamaah yang variatif dan tidak menetap disebabkan oleh faktor lingkungan dan letak masjid misalnya beberapa jemaah berasal dari pegawai perkantoran dan mahasiswa disekeliling masjid. Pemimpin shalat jamaah lima waktu adalah imam tetap yang ditunjuk berdasarkan SK yang dikeluarkan oleh Bupati Polewali Mandar.

Sebelum ibadah shalat dimulai terdapat kegiatan yang mendahuluinya antara lain pengajian (kaset), tahrim, dan azan dengan menggunakan pengeras suara. Teknik pelaksanannya berbeda pada lima waktu. Sebelum azan diputarkan kaset pengajian dan tahrim sekitar 15-20 menit pada waktu Subuh.Magrib dan Isya hanya tarhim 10 sekitar menit sebelum waktu azan sedangkan Dhuhur dan Ashar langung azan sebagai seruan panggilan menunaikan shalat.

Padahal berdasarkan Keputusan Lokakarya Pembinaan Kehidupan Agama Islam (P2A) tentang penggunaan pengeras suara di masjid dan mushallah oleh Direktur Jendral Bimbingan Masyarakat Islam Nomor: KEP/D/101/1978, bahwa waktu subuh paling awal 15 menit sebelum waktunya, sedangkan waktu lain 5 menit untuk pembacaan ayat-ayat alQuran, kemudian azan dengan menggunakan pengeras suara dengan "suara keluar". Sedangkan shalat, kuliah Subuh, doa, pengumuman, khubah, dan lain-lain menggunakan "suara ke dalam". (Departemen Agama RI Direktorat Jenderal Bimbingan Masyarakat Islam dan Urusan Haji, 1999/2000: 140-147).Penggunaan suara dengan volume yang tinggi diasumsikan dapat mengganggu umat lain. 
Inisiatif pengurus masjid menggunakan pengeras suara ke luar tidak sesuai dengan KEP/D/101/1978dengan alasan menitik beratkan pada nuansa syiar, sehingga komunitas yang mayoritas muslim di sekitar lingkungan masjid tidak tergesa-gesa dalam mempersiapkan diri ke masjid. Alasan lain bahwa sampai sekarang ini belum terdapat pengaduan dari komunitas lain.

\section{b. Shalat Jumat}

Masjid Agung Syuhada pada hari Jumat dipenuhi oleh jamaah, bukan saja dari masyarakat yang bermukim di sekitar masjid tetapi juga dari beberapa pegawai instasi dan masyarakat yang lewat karena tempat masjid yang sangat strategi berada di jalan poros trans Makassar-Mamuju disamping berada dijantung kota Polewali.

Rangkaian pelaksanaan shalat Jumat didahului tarhim yang berlangsung sekitar 1 (satu) jam, sebelum dikumandangkan azan.Di masjid Syuhada menggunakan dua kali azan. Pertama sebelum khatib memulai khutbahnya, dan kedua setelah khatib member salam pembukaan untuk khutbahnya.

Para khatib sudah terdaftar dalam jadwal khutbah Jumat yang telah disusun sebelumnya oleh pengurus masjid.Jadwal khutbahnya telah dipersiapkan setiap 3 (tiga) bulan untuk penceramahnya, dan jadwal tersebut tertempel di papan pengumuman masjid. Untuk penentuan kriteria penceramah tidak ada kriteria tersendiri, hanya berdasarkan faktor kebiasaan, atau orang yang telah dikenal, yang biasa membawakan khutbah jumat sebelumnya. Bila terdapat khatib yang berhalangan maka harus melaporkan kepada pengurus masjid sehari sebelum pelaksanaan shalat Jumat.Namun misalnya ada tamu masjid, yang kapabel untuk menyampaikan khutbah jumat, maka akan didahulukan tamu tersebut untuk khutbah, namun tetap dikonfirmasi dengan pengkhutbah yang telah dijadwalkan.

\section{c. ShalatTarwih dan Tasbih}

Selain tempat pelaksanaan lima wajib, pelaksaan shalat tarawih juga dilakukan di Masjid Syuhada setiap malam dalam bulan Ramadhan. Jumlah rakaat shalat tarawih yang dilakukan adalah 20 rakaat.Namun bagi yang delapan rakaat juga dapat bergabung sampai rakaat kedepalan dan 
shalat witirnya dilakukan masing-masing.Untuk pelaksanaan shalat tasbih selalu dilakukan kalau 27 Ramadhan juga, begitupun juga i` tikaf.

\section{d. Pengajian Dasar}

Salah satu bentuk pendidikan yang dilaksanakan di Masjid Syuhada Polman adalah pengajian dasar bagi anak-anak yang dilakukan setiap sore, setelah Shalat Ashar sampai menjelang Magrib. Pengajian dasar ini tidak dikemas dalam bentuk TPA. Kegiatan spesifik anak-anak yang mengaji Alquran dasar tersebut dibimbing oleh 1 orang guru mengaji yang bernama Syamsuddin, hal tersebut dikarenakan jumlah murid yang terbatas, yakni hanya 10 anak.

Meskipun kegiatan tersebut sudah berlangsung sejak tahun 1990an, namun, sampai sekarang belum ada peningkatan signifikan, terkait jumlah murid dan guru pengajarnya. Meskipun beberapa usaha telah dilakukan oleh pengurus masjid, diantaranya dengan mengumumkan setiap hari Jumat sebelum shalat Jumat dilakukan, bahwa di Masjid Syuhada dilakukan pengajaran baca tulis al-Quran bagi anak-anak. Namun upaya itu juga belum menemui hasil yang maksimal.

Pihak pengurus telah menyiapkan penambahan guru mengaji untuk anak-anak di Masjid Syuhada, namun karena jumlah murid yang sangat terbatas, maka niat itu pun belum terealisasi.Untuk insentif guru mengaji dari kegiatan tersebut sebesar 200ribu/bulan, yang dianggarkan oleh pengurus masjid dan ada juga tambahan insentif 100.000/bulan dari Kementerian Agama Polman, disamping ada pula insentif dari pihak Pemda Polman yang diterima oleh guru mengaji tersebut setia enam bulan sekali.

\section{e. Perayaan Hari Besar Islam}

Untuk menyemarakkan syiar Islam pengurus masjid selalu mengadakan kegiatan yang berkaitang dengan peringatan hari besar Islam. Adapun hari besar Islam yang diperingati di Masjid Agung Syuhada Polman diantaranya Maulid nabi, Isra Mi'raj, tahun baru Islam, dan nuzulul Qur'an dan tahun baru hijriyah.

Pelaksanaan hari besar Islam (HBI) pada umumnya diisi dengan ceramah agama dan beberapa sambutan dari pejabat pemerintah.Muballig yang diundang membawakan ceramah agama. Tabligakbar sering juga 
dilaksanakan di Masjid Agung Syuhada yang mendatangkan muballig dari luar Polman hal ini bertujuan untuk menambah wawasan keagamaan masyarakat. Acara tablig dilakukan atas kerjasama pengurus masjid dengan pemerintah kabupaten.

\section{f. Pengajian}

Selain ceramah melalui khutbah dan peringatan HBI, di masjid Syuhada sampai sekarang melakukan kegiatan yang masih "continue" yaitu ceramah yang dilakukan sehabis shalat Subuh (kultum). Kegiatan itu diikuti oleh jamaah tetap Masjid Syuhada yang berkisar 50 jamaah, terdiri dari 40 jamaah laki-laki dan 10 orang jamaah perempuan.

Meskipun, dulu pernah ada ceramah-ceramah yang dilakukan sehabis Shalat Magrib, namun kegiatan itu tidak bisa bertahan, dan intensitasnya sangat lemah. Karena sampai sekarang, kegiatan tersebut kadang dilakukan dan kadang juga tidak ada yang mengisi ceramahnya.

Hanya, pada waktu bulan Ramadhan, ceramah dan kultum dilakukan sebulan penuh. Hak itu dikarenakan biasa ada juga yang dari santri dari pesantren-pesantren dari Sengkang, Makassar, Enrekang dan daerah lain yang mengisi ceramah.

\section{g. Bimbingan Manasik dan Pelepasan Calon Jemaah Haji}

Bimbingan manasik haji secara masal dilaksanakan di Masjid Agung Syuhada setiap tahun oleh Departemen Agama bekerjasama dengan pemerintah kabupaten. Masjid Agung Syuhada dipilih sebagai tempat bimbingan dan pelepasan calon jemaah haji karena tempatnya sangat strategi dan mudah dijangkau dari berbagai arah.

Pelepasan calon jemaah haji yang dilakukan setiap tahun sebelum masuk pada asrama haji di Makassar. Acara pelepasan dihadiri seluruh jemaah haji (sesuai keloter) dan pejabat pemerintah.Program haji gratis bagi para imam masjid Polman yang dilakukan oleh Pemkab dan termasuk imam Masjid Syuhada Polman terjaring dalam program tersebut.Program ini dilakukan dalam memperingati hari ulang tahun Polman.

\section{h. Jumat Bersih}

Di Masjid Syuhada, biasanya juga dilakuakan kerja bakti, tapi untuk waktunya dikondisikan, meskipun dilaksanakan pula Jumat bersih. Setiap Jumat mulai jam 9 pagi para jamaah sudah berkumpul untuk 
membersihkan tempat wudhu dan lingkungan masjid. Namun hal ini tidak dilakukan secara rutin tergantung situasi kebersihan lingkungan sekitar masjid.

\section{i. Remaja Masjid}

Kegiatan lain seperti remaja masjid, sampai sekarang tidak ada, meskipun pernah ada pada tahun 1980-1990-an. Kepengurusan Ramaja Masjid Syuhada terakhir kali pada tahun 1995, dan setelah itu belum ada terbentuk pengurus Ramaja Masjid sampai sekarang ini.

\section{j. Petugas Kebersihan}

Untuk kebersihan masjid, ada petugas tersendiri yang terdiri dari dua orang yang bertanggung jawab untuk kebersihan di dalam masjid, dan satu orang diluar, atau halaman masjid. Untuk intensifnya, digaji oleh masjid dengan jumlah 250 ribu perbulan ditambah intensif dari daerah bidang kesra Pemkab Polman yang diterima setiap enam bulan sekali.

Gaji intensif tersebut termasuk penggajian sebagai kette, terdapatdua orang katte, juga sebagai muazzin, dan sebagai protocol masjid yakni Syamsuddin. Dialah yang membuka dan menutup masjid, dia juga biasa jadi imam pengganti jika imam tetap berhalangan, dia pula yang merangkap mengajar mengaji anak-anak. Insensifnya itu sekitar satu juta (Rp.1000.000,-) perbulan, karena model penggajiannya dilakukan setiap Jumat sebesar 250ribu. Ada juga Samsuddin,tukang yang bertugas membantu Syamsuddin(kedua Samsuddin tersebut yang bertugas sebagai katte).

\section{k. Sumber Pendanaan}

Untuk donatur masjid, ada donator tetap yang memiliki kartu donator. Jumlah donator tetap Masjid Syuhada berjumlah 40 orang. Untuk pengumuman keuangan Masjid diumumkan setiap Jumat dipapan pengumuman lengkap dengan donaturnya, jadi tidak ada pengumuman melalui protokol shalat Jumat kalau menjelang shalat Jumat terkait maslah keuangan, hal yang bertujuan supaya tidak mengganggu proses shalat Jumat.Jadi siapapun yang mau lihat keadaan keuangan masjid Syuhada terpampang dengan jelas di papan pengumuman. Sedangkan untuk jumlah uang tabungan masjid setiap Jumatnya, tidak kurang dari Rp.1.000.000,-. 


\section{Simpulan}

Posisi masjid agung yang diasumsikan sebagai masjid yang representatif di tingkat kabupaten, dan masjid raya ditingkat provinsi yang dijadikan sebagai model pelayanan dan pengelolaan yang memenuhi standar, namun fakta dilapangan menunjukkan sistem pengelolaan dan manajemennya masih di bawah standar. Standarmanajemen atau pengelolaan masjid yang ideal yang sesuai dengan standar diberlakukan oleh Direktorat Urusan Agama Islam dan syariah yang didasarkan pada fungsi masjid. Peran dan fungsi yang dimainkan oleh Masjid Agung Syuhada Polewali Mandar Sulawesi Barat hanya sebatas pada pelayanan ibadah rutin, pengajian dasar secara tradisional, dan pelaksanaan HBI (Hari Besar Islam). 


\section{BIBLIOGRAFI}

Amidan. 1981. Pedoman Pembinaan Masjid. Jakarta: Departemen Agama Bimas Islam dan Urusan Haji, Direktorat Urusan Agama Islam, Proyek Pembinaan Sarana Keagamaan Islam.

Departemen Agama RI Direktorat Jenderal Bimbingan Masyarakat Islam dan Urusan Haji.1999/2000.Pola Pembinaan Kegiatan Kemasjidan dan Profil Masjid, Mushalla dan Langgar.Jakarta: Departemen Agama RI Direktorat Jenderal Bimbingan Masyarakat Islam dan Urusan Haji dengan Proyek Peningkatan Sarana Keagamaan Islam Zakat dan Wakaf.

Direktorat Urusan Agama Islam dan Pembinaan Syariah Departemen Agama. 2008. Pedoman Pembinaan Kemesjidan. Jakarta: Direktorat Urusan Agama Islam dan Pembinaan Syariah Departemen Agama.

. 2007. Tipologi Masjid. Jakarta: Direktorat Urusan Agama Islam dan Pembinaan Syariah bekerjasama dengan Direktorat Jenderal Bimbingan Masyarakat Islam Departemen Agama RI.

. 2008. Manajemen Kemesjidan Dilengkapi Petunjuk Arah Kiblat. Jakarta: Direktorat Urusan Agama Islam dan Pembinaan Syariah Departemen Agama Republik Indonesia.

Dokumen Pemkab Polman mengenai mengukuran kembali masjid Syuhada Pekkataba Polewali Nomor 308 tahun 2007 tanggal 23 Oktober 2007.

Dokumen Pengadilan Agama Polewali Nomor: PA.t/21/K/HK.03.2/ SK.05/2006 mengenai Tim pengukuran arah kiblat masjid kabupaten Polewali Mandar.

Gazalba, Sidi. 1975. Masjid Pusat Ibadat dan Kebudayaan Islam. Jakarta: Pustaka Antara.

Idham. 2011. "Buah Pena Sang Ulama” dalam Annangguru Muhammad Shaleh Pembawa Tarekat Qadiriyah di Tanah Mandar. Orbit: Publising Jakarta. 
Jasmadi. 2008. "Revitalisasi Fungsi Masjid Sebagai Basis Pengembangan Masyarakat Islam” dalam Komunitas, Jurnal Pengembangan Masyarakat Islam. Volume 4, Nomor 1, Juni 2008.

Muslim,Aziz.2004. "Manajemen Pengelolaan Masjid” dalam Aplikasia, Jumal Aplikasi llmu-ilmu Agama, Vol. V, No. 2, Desember 2004.

Sule, Ernie Tisnawati dan Kurniawan Saefullah. 2008. Pengantar Manajemen. Jakarta: Kencana Prenada Media Group.

Syahidin.2004. Pemberdayaan Umat Berbasis Masjid.Bandung: Alfabeta.

Yatim, Badri. 2006. Sejarah Peradaban Islam. Jakarta: Raja Grafindo Persada. 
